\title{
Measuring the Remode Entreprenurship Training Programme at Behaviour Level of Kirkpatrick Model in Aquaculture Industry
}

\author{
Anis Amira Ab. Rahman ${ }^{1}$, Mohd Rafi Yaacob ${ }^{1}$, Mohd Asrul Hery Bin Ibrahim ${ }^{1}$, Nor Shuhada Ahmad Shaupi ${ }^{1}$, \\ P.Yukhamarani A/P Permarupan ${ }^{1}$ \& Azlinda Shazneem Md Shuaib ${ }^{1}$ \\ ${ }^{1}$ Universiti Malaysia Kelantan, Malaysia \\ Correspondence: Anis Amira Ab. Rahman, Universiti Malaysia Kelantan, Malaysia.
}

Received: May 1, 2019

Accepted: June 1, 2019

Online Published: July 7, 2019

doi:10.5430/rwe.v10n2p1

URL: https://doi.org/10.5430/rwe.v10n2p1

\begin{abstract}
The objective of this paper is to reveal the findings which regard to the behaviour level of the Bottom 40 that involved in REMODE training programme. Bottom 40 is a group of household income that lower than RM3,900 per month. The aim of REMODE training programme is to increase the entrepreneurship knowledge that relates to aquaculture industry for poverty eradication. Previous studies on entrepreneurship training programme indicate that utilisation of Kirkpatrick model to measure the impact at behavioural level is still scarce. Most of the study only focuses on the reaction and learning Level. Therefore, this study measured the behavioural level of Bottom 40 who involved in REMODE training programme in order to evaluate the effectiveness of entrepreneurship training programme to fill in the empirical gaps. A qualitative approach using Focus Group Discussion was used to gather data from five groups that consist of twenty three participants. The findings from narrative thematic analysis show that the participants experienced business growth, business diversification, product innovation and business records management due to the knowledge application. This study contributes to the entrepreneurship body of knowledge from the entrepreneurship training perspective. Future research should explore the different type of entrepreneurship training programme measurement and also application to the different type of participants.
\end{abstract}

Keywords: entreprenurship, aquaculture industry, trainings

\section{Introduction}

Training is an activity that changes people's behaviour (Ghosh et al., 2011) which able to increase the entrepreneurs' skills. It must be practical in nature and the entrepreneurs can learn through application, experiences, examples and mistakes (Nyambura, 2014; Abdullahi, Baba \& Musa 2017). The achievement of knowledge and skills during training contributes to the organizational decision for financial and material resources investment in future (Kraiger, McLinden \& Casper, 2004)

Sarri, Bakouros \& Petridou (2010) indicate that training programmes can enhance entrepreneurial performance which relates to the knowledge of administrative, organisational, creativity, innovation management, employment and changes to working environment. The training programme has potential to develop the thought-style and skills for identificaton of creativity, business opportunity, logical and problem solving; and to increase the people's knowledge and skills (Alarape, 2007 \& Idrus, Pauzi \& Munir, 2014). It also can help entrepreneurs to create new businesses, manage business growth and generate new jobs (Idrus, Pauzi \& Munir, 2014). The trained participants must understand the knowledge in order to actively involve in entrepreneurial activities (Mensah \& Benedict, 2010, Adegbite, 2017).

Hence, this study uses Kirkpatrick's Model as an evaluation tools to evaluate this REMODE entrepreneurship training programme from the behavioural perspective. This model has four types of evaluation namely, Level 1 - Reaction; Level 2 - Learning; Level 3 -Behaviour; and Level 4 - Result (Kirkpatrick, 1994). This paper will only reveal the result on Level 3 (Behaviour) because this stage is the most crucial stage that infer the practices of the knowledge from the programme.

\section{Entrepreneurship Training Evaluation}

\subsection{REMODE Training Programme}

Entrepreneurship training programme (REMODE) is a six weeks training programme that relates to entrepreneurship 
and aquaculture industry knowledge which involves the paticipation of Bottom 40 . Bottom 40 is a group of low household income with less than RM3,900 per month. The objective of this programme is to incalcate the entrepreneurship knowledge for the purpose of poverty eradicate. The programme utilised experts from Universiti Malaysia Kelantan itself and industry experts for knowledge transfer. This training programme consists of six sessions of training. The modules covered are Module I (Reflection of Entrepreneurship), Module II (Enterprise), Module III (Managing Enterprise), Module IV (Operation for Aquaculture Industry), Module V (Development) and Module VI (Sustainability).

\subsection{Training Evaluation}

The training evaluation of Kirkpatrick Model is an approach for measuring the effectiveness of REMODE training programme (Kirkpatrick, 1975). The first level is 'reaction' which measures the states of the participants that relates to the context of the training programme (Kirkpatrick \&, 1975). Level 2 is 'learning' which measure the increasing of knowledge based on the content of training programme (Kirkpatrick, 2010). Level 3 is 'behaviour' that measure the extent to which the training transfer the knowledge into action (Kirkpatrick \& Kirkpatrick, 1994). Level 4 is 'result' which measurement indicates the performance whether the return of expectation is achieved (Kirkpatrick, 2010).

\subsection{Level 3: Behaviour}

Level 3 is referring to behaviour measurement. The behaviour measurement indicates the extent to which the training transfers their knowledge to the actions at their workplace (Kirkpatrick, 2010). Steensma \& Groeneveld (2010) state that trainee who has participated in the management training programme scored much better on the behavioural measurement. Thus, behaviour level is often complicated to evaluate because of time factor (Kong, 2016). On the other hand, reaction of Level 1 and learning of Level 2 are measures directly after the training event (Aluko, 2014, Al Shamsi \& Alsinani 2018).

Furthermore, Level 3 outcomes are required for measuring Level 4 outcomes (Havens et al., 2006). In many situations, evidence of Level 1 outcome, Level two outcomes, and Level 3 outcomes will be sufficient evidence of the merit and usefulness of a training programme (Kong, 2016). In sum, the behaviour level will be measured the critical behaviour of trainee.

\section{Methodology}

This study employs qualitative approach with subjectivism perspective using idealist ontology and constructivism epistemology. Focus group discussion with purposive sampling technique has been utilised to achieve the research objectives. Five small groups of 23 'Bottom 40' participants gathered to discuss a specified topic with objective to understand the participants' knowledge, perspectives and attitudes on the issues (McLafferty, 2004 \& Kreuger, 2014, Adusei, 2018). Narrative analysis was employed to analyse the data source (Riesman, 1993).

\section{Findings}

\subsection{Business Growth}

It is found that the participants show the changes and improvement in terms of their business growth due to the application of REMODE knowledge. In which they undertake their business thrive in terms of total sales, product demand and the desire to offer their creative product. The participants able to apply knowledge and skills in their business itself as indiated below:

"This entrepreneurship training programme changed my business life. There are so many new things that can I learn through this programme that I have never had before. For example, this programme teaches how to promote our products and services in a smart way, how to survive in the industry, our products are known and viral. This marketing method allows me to apply in my business. Now, I am success to boost the market through sales of 'meatballs' using freshwater fish as a base.". (R16)

\subsection{Business Diversification}

Business diversification is about the business strategy on how to enter into a new market using knowledge achieved, and also creating a new product. The training participants have courageous in managing the business because they have creative mind after they involved in REMODE training programme. One of the training participants is willing to share her skills by conducting training in product development. This is because the participants have confidence in the diversity of skills in doing business. Feedback given as below:

"After attended the entrepreneurship programme provided by Universiti Malaysia Kelantan, there are many improvement that have arisen in my business. I have the ability to improve the business and to increase the 
business income business diversification. For me, I am more enthusiastic and self-confidently and like to make a change. In addition, the benefits given in the programme can also benefit to my customers which is I offered a training sessions and knowledge sharing in the manufacture of bakery based products. The customers were happy with the bakery class that I given and shared."(R8)

\subsection{Product Innovation}

Participants are involved in entrepreneurship training programme used the knowledge to carry out process innovation such as improving production or delivery method. Participants also have the desire to change existing products or create new products to further improve their business performance. They also point out that the quality of the offered products has improved. Participants also creative in using tilapia fish fillet as a base in creating fish balls for sale of 'meatballs' and mixing with other ingredients. Thus, they are innovative in producing and creating products after attended this programme. Feedback given as below:

"Now there is a fish-based food product. Most of the marine fish are used as raw material but we can create innovation on the product by using freshwater fish. Now I have curry puff products using this freshwater fish. For customers in Kelantan, a slightly sweet recipe is used. Whereas for customers in the south, the demand for the spicy. After making an experiment in the making of this curry puff, the tilapia fish is the best which is delicious tasty and smelly fish. I hope that this innovation that I am doing is getting a high demand in Malaysia."(R21).

\subsection{Business Records}

Financial plans are important in a business. The participants are able to know and determine the costs involved in business management such as the amount of funding needed, the cash flow in the business, the payment of instalment, and the amount of sales through the financial plan. Participants in the programme learnt and have utilised the knowledge practically in order to ensure their business operate in systematically and effectively. This shows that the knowledge learned about business records is very useful. Participants also know how and where to use the knowledge and skills. Feedback given as below:

"After I joined this entrepreneurial training programme, my business situation changed 100\% because the knowledge was given in managing business was very useful. I have also practiced such skills as recording by providing cash flow, profit and loss statements and balance sheets in my grocery shop. Such a related to profit and loss can now be seen. This knowledge really helps me to be disciplined more efficient in manage the business"

\section{Discussions and Conclusion}

The measurement of the REMODE training participants indicates that training programme is effective due to the evidence of behavioural changes. The knowledge that participants gain during the training is translated with the evidences of business growth, business diversification, product innovation and business record management. Previous studies have indicated that business diversification, product innovation and proper business record management contribute to the business performance (Tallman \& Li, 1996, Prakash \& Gupta, 2008 \& Klein, 2003). The increasing of business performance and business growth will increase the household income (Mishra, 2002, Aktaş, 2018) and this situation will help in the proses of poverty eradication (Mensah \& Benedict, 2010 \& Ogundele \& Akingbade, 2012, Adusei, 2018).

To conclude, this study has proven that the "REMODE", an entrepreneurship training programme is effective. This study also contribute to the original knowledge of entrepreneurship field empirically, by finding that business diversification is one of the factors that can be aimed from the output of entrepreneurship training programme. This REMODE programme also can be used in the government agency to increase the number of entrepreneurs especially aquaculture entrepreneur and achieve the poverty eradication objective. Future research should try to use different model of measurement and also test the REMODE to the different type of participants.

\section{Acknowledgement}

This research was funded by the Ministry of Higher Education, Malaysia under the grant entitled "Developing Entrepreneurship Training Programme through the Rural Entrepreneurship Model (REMODE) for Aquaculture Industry" (R/NRGS/A01.00/280A/004/2014/000153).

\section{References}

Abdullahi, D., Baba, Y. T., \& Musa, A. (2017). Thuggery of Liberation and Election in Kebbi State. International Journal of Social and Administrative Sciences, 2(1), 8-14. 
Adegbite, T. (2017). Personal Income Tax and Government Revenue: Evidence from Oyo State. International Journal of Social and Administrative Sciences, 2(2), 45-51.

Adusei, C. (2018). Determinants of Non-Performing Loans in the Banking Sector of Ghana between 1998 and 2013. Asian Development Policy Review, 6(3), 142-154.

Adusei, C. (2018). Public Procurement in the Health Services: Application, Compliance and Challenges. Humanities and Social Sciences Letters, 6(2), 41-50.

Aktaş, M. (2018). Identifying the Effects of Mergers and Acquisitions on Turkish Banks' Performances. Asian Journal of Economic Modelling, 6(3), 235-244.

Al Shamsi, I. R. H., \& Alsinani, S. (2018). A Study of Organizational Factors and Employee Retention: The Case of Ministry of Civil Service in Oman. Journal of Accounting, Business and Finance Research, 3(2), 72-82.

Alarape, A. A. (2007). Entrepreneurship programs, operational efficiency and growth of small businesses. Journal of Enterprising Communities: People and Places in the Global Economy, 1(3), 222-239.

Aluko, F. R., \& Shonubi, O. K. (2014). Going beyond Kirkpatrick's Training Evaluation Model: The role of workplace factors in distance learning transfer. Africa Education Review, 11(4), 638-657.

Basch, C. E. (1987). Focus group interview: an underutilized research technique for improving theory and practice in health education. Health education quarterly, 14(4), 411-448.

Ghosh, P., Joshi, J. P., Satyawadi, R., Mukherjee, U., \& Ranjan, R. (2011). Evaluating effectiveness of a training programme with trainee reaction. Industrial and Commercial Training, 43(4), 247-255.

Kirkpatrick, D. L. (Ed.) (1975). Evaluating training programs: A collection of articles from the Journal of the American Society for training and development. Madison, WI: American Society for Training and Development.

Kirkpatrick, J. D., \& Kirkpatrick, W. K. (2010). Using evaluation results. ASTD Handbook of measuring and evaluating training, 265.

Kitzinger, J. (1995). Qualitative research: introducing focus groups. Bmj, 311(7000), 299-302.

Klein, J., I. Alisultanov \& A. Blair (2003). Microenterprise as welfare to work strategy: Two-year findings. Washington, D.C: The Aspen Institute.

Kong, H. (2016). A critical analysis of a program evaluation: a case study on the effectiveness of a teacher training program. Asian Journal of Educational Research, 4(5), 24-33.

Kraiger, K., McLinden, D., \& Casper, W. J. (2004). Collaborative planning for training impact. Human Resource Management, 43(4), 337-351. https://doi.org/10.1002/hrm.20028

Krueger, R. A., \& Casey, M. A. (2014). Focus groups: A practical guide for applied research. Sage publications.

McKinley R. K., Manku-Scott, T., Hastings, A. M., French, D. P., \& Baker, R. (1997, January). Reliability and validity of a new measure of patient satisfaction with out of hours primary medical care in the United Kingdom: development of a patient questionnaire. British Medical Journal, 314(18), 193-19.

McLafferty, I. (2004). Focus group interviews as a data collecting stratergy. Journal Adv Nurse, (48), 187-194.

Mensah, S. N., \& Benedict, E. (2010). Entrepreneurship training and poverty alleviation: Empowering the poor in the Eastern Free State of South Africa. African Journal of Economic and Management Studies, 1(2), 138-163.

Mishra, A. K., El-Osta, H. S., Morehart, M. J., Johnson, J. D., \& Hopkins, J. W. (2002). Income, wealth, and the economic well-being of farm households. Washington DC: U.S. Department of Agriculture, Economic Research Service. Agri - Cultural Economic Report Number, (812), 20036-5831.

Nieman, G. (2001). Training entrepreneurs and small business enterprises in South Africa: A situational analysis. Education \& Training, 43(8/9), 445-50.

Ogundele, O. W., \& Akingbade, H. A. (2012). Entrepreneurship training and education as strategic tools for poverty alleviation in Nigeria. American International Journal of Contemporary Research, 2(1), 148-156.

Otley, D., \& Pollanen, R. M. (2000). Budgetary criteria in performance evaluation: a critical appraisal using new evidence. Accounting, organizations and Society, 25(4-5), 483-496.

Prakash, Y., \& Gupta, M. (2008). Exploring the relationship between organisation structure and perceived innovation 
in the manufacturing sector of India. Singapore Management Review, 30(1), 55-76.

Riesman, C. K. (1993). Narrative Analysis. Newbury Park, CA: Sage.

Sarri, K. K., Bakouros, I. L., \& Petridou, E. (2010). Entrepreneur training for creativity and innovation. Journal of European Industrial Training, 34(3), 270-288.

Steensma, H., \& Groeneveld, K. (2010). Evaluating a training using the "four levels model". Journal of Workplace Learning, 22(5), 319-331.

Tallman, S., \& Li, J. (1996). Effects of international diversity and product diversity on the performance of multinational firms. Academy of Management Journal, 39(1), 179-196.

Wong, L. P. (2008). Focus group discussion: a tool for health and medical research. Singapore Med J, 49(3), $256-60$. 